\title{
Metabolic and Biochemical Responses of Probiotic Bacteria to Oxygen
}

\author{
A. Talwalkar and K. Kailasapathy \\ Centre for Advanced Food Research, University of Western Sydney, \\ Locked Bag \#1797, SPDC, NSW 1797, Australia
}

\begin{abstract}
The interaction between oxygen and probiotic bacteria was studied by growing Lactobacillus acidophilus and Bifidobacterium spp. in 0, 5, 10, 15, and $21 \%$ oxygen in a hypoxic glove box. The metabolic responses of each probiotic strain in the different oxygen environments were monitored by measuring the levels of lactic acid and determining the lactate-to-acetate ratio. Biochemical changes induced by oxygen were examined by monitoring the specific activities of NADH oxidase, NADH peroxidase, and superoxide dismutase. In addition, the ability to decompose hydrogen peroxide and the sensitivity of each strain to hydrogen peroxide was also determined. With an increase in oxygen percentage, levels of lactic acid in $L$. acidophilus strains decreased, whereas the lactate-to-acetate ratio reduced in all the bifidobacteria tested. At $21 \%$ oxygen, the specific activities of NADH oxidase and NADH peroxidase, and the hydrogen peroxide decomposing ability of five probiotic strains was significantly higher than at $0 \%$ oxygen. The sensitivity of the probiotic strains to hydrogen peroxide however, remained unaffected in all the different oxygen percentages. Superoxide dismutase levels did not reveal any conclusive trend. In both $L$. acidophilus and Bifidobacterium spp., NADH oxidase and NADH peroxidase functioned optimally at $\mathrm{pH} 5$. Growth in the various oxygen environments did not change this optimum $\mathrm{pH}$.
\end{abstract}

(Key words: probiotic bacteria, oxygen, metabolic and biochemical response)

Abbreviation key: $\mathrm{H}_{2} \mathrm{O}_{2}=$ hydrogen peroxide, $\mathbf{N A D H}$ $=$ reduced $\mathrm{NAD}, \mathbf{S O D}=$ superoxide dismutase .

\section{INTRODUCTION}

The various therapeutic benefits of probiotic bacteria such as Lactobacillus acidophilus and Bifidobacterium

Received December 10, 2002.

Accepted March 26, 2003.

Corresponding author: K. Kailasapathy; e-mail: k.kailasapathy@ uws.ed.au. spp. (Kailasapathy and Chin, 2000) have led to their increased incorporation in dairy foods such as yogurts (Lourens-Hattingh and Viljoen, 2001). The poor survival of probiotic bacteria in commercial yogurts (Shah et al., 1995; Rybka and Fleet, 1997; Shah et al., 2000) below the recommended $10^{6} \mathrm{cfu} / \mathrm{g}$ (IDF, 1992), however, can limit their ability to exert positive health benefits in humans (Kurmann and Rasic, 1991). Among the reasons responsible for the loss in probiotic viability, cell death due to oxygen toxicity is considered a significant factor (Brunner et al., 1993; Klaver et al., 1993; Dave and Shah, 1997).

The problem of oxygen toxicity in probiotic bacteria, however, remains poorly understood. Although probiotic bacteria, especially bifidobacteria, are considered as highly susceptible to oxygen, the oxygen tolerance of these organisms has been strain dependent (de Vries and Stouthamer, 1969; Shimamura et al., 1992; Talwalkar et al., 2001). Satisfactory growth of a variety of Bifidobacterium spp. in the absence of strict anaerobic conditions was observed by Cheng and Sandine (1989). In another study, B. lactis, isolated from fermented milk was found to display good oxygen tolerance (Meile et al., 1997).

It is believed that intracellular levels of $\mathrm{H}_{2} \mathrm{O}_{2}$ block fructose 6 phosphofructoketolase, a key enzyme in the sugar metabolism of bifidobacteria and therefore scavenging $\mathrm{H}_{2} \mathrm{O}_{2}$ becomes important for cell survival (de Vries and Stouthamer, 1969). Both L. acidophilus and Bifidobacterium spp. are devoid of catalase, a key enzyme for the breakdown of $\mathrm{H}_{2} \mathrm{O}_{2}$ and have to rely on enzymes such as NADH oxidase and $\mathrm{NADH}$ peroxidase to scavenge environmental oxygen (Condon, 1987). The activities of NADH oxidases in probiotic bacteria give rise to $\mathrm{H}_{2} \mathrm{O}_{2}$, prompting $\mathrm{NADH}$ peroxidase to scavenge $\mathrm{H}_{2} \mathrm{O}_{2}$ and prevent cell death. Shimamura et al. (1992) explored the biochemical mechanisms of oxygen sensitivity of several bifidobacteria and concluded that levels of NADH oxidase and NADH peroxidase play an important role in the prevention of oxygen toxicity. High levels of these enzymes were found in the most aerotolerant Bifidobacterium spp.

So far, oxidative studies on probiotic bacteria have mainly focused on bifidobacteria (de Vries and Stou- 
thamer, 1969; Shimamura et al., 1992; Ahn et al., 2001). Furthermore, in the reported studies on bifidobacteria and $L$. acidophilus, the cells were grown in either aerobic or partially aerobic conditions (Archibald and Fridovich, 1981; Shimamura et al., 1992; Ahn et al., 2001). These undefined concentrations of oxygen may be unsuitable for identifying definitive relationships between the effects of different oxygen concentrations on probiotic bacteria. Understanding the precise metabolic and biochemical changes influenced by known amounts of oxygen is crucial for preventing the problem of oxygen toxicity in probiotic bacteria.

Therefore, in this study, four Bifidobacterium spp. and two L. acidophilus strains were grown individually in $0,5,10,15$, and $21 \%$ oxygen in a hypoxic glove box and their metabolic and biochemical responses to oxygen were monitored. Metabolic responses were examined by the measurement of lactic acid and acetic acid levels. The sensitivity of the probiotic strains to different $\mathrm{H}_{2} \mathrm{O}_{2}$ concentrations in each oxygen percentage was also tested. Furthermore, the ability of the strains to decompose known amounts of $\mathrm{H}_{2} \mathrm{O}_{2}$ was examined. Specific activities of NADH oxidase, $\mathrm{NADH}$ peroxidase, and SOD were regarded as biochemical indices of the probiotic bacterial strains and were measured accordingly. The defined concentrations of oxygen allowed us to study the incremental build up of the oxidative stress response of the probiotic bacteria.

\section{MATERIALS AND METHODS}

\section{Organisms and Culture Conditions}

Lactobacillus acidophilus 2400, L. acidophilus 2409, Bifidobacterium infantis 1912, Bifidobacterium lactis 1941, Bifidobacterium pseudolongum 1944 were supplied by Commonwealth Scientific Industrial Research Organization (CSIRO) stock culture collection, Australia. Bifidobacterium longum 55815, an oxygen-resistant strain was obtained from ATCC (Manassas, VA). One hundred microliters of an 18-h-old inoculum of these strains grown anaerobically in MRS broth (Oxoid, Australia) with $\mathrm{A}_{600 \mathrm{~nm}}$ of 0.6 was added aseptically to 200 $\mathrm{ml}$ of MRS broth in a 500-ml conical flask and stoppered with a cotton plug. Each strain was grown under 0, 5, 10,15 , and $21 \%$ oxygen at $37^{\circ} \mathrm{C}$ for $24 \mathrm{~h}$ using a hypoxic glove box (Coy Laboratory Products, Grass Lake, MI). At $0 \%$ oxygen, the glove box contained a gaseous atmosphere of $95 \% \mathrm{~N}_{2}$ and $5 \% \mathrm{H}_{2}$. The various oxygen concentrations in the glove box were created by replacing hydrogen with oxygen and adjusting the nitrogen levels accordingly. Each culture was tested in duplicate. The flasks containing the culture broth were agitated using a magnetic stirrer. The culture broth after incubation was centrifuged at $10,000 \times g$ for $20 \mathrm{~min}$ at $4^{\circ} \mathrm{C}$. The cell free supernatant was used to estimate lactic acid and acetic acid. The cell pellet was washed three times with $0.1 M$ phosphate buffer, $\mathrm{pH} 7.0$, and part of it was used for the determination of $\mathrm{H}_{2} \mathrm{O}_{2}$ decomposing ability and the sensitivity to $\mathrm{H}_{2} \mathrm{O}_{2}$. The remaining cell pellet was used for preparing the cell free extract.

\section{Preparation of Cell Free Extract}

The washed cell pellet suspended in $0.1 M$ phosphate buffer ( $\mathrm{pH} 7$ ) was passed through a French $20 \mathrm{~K}$ pressure mini-cell (Spectronic, USA) at 20,000 psi. Cell debris was removed from the cellular contents by centrifugation at $12,000 \times g$ for $15 \mathrm{~min}$. The cell free extract collected was used for assaying levels of $\mathrm{NADH}$ oxidase, NADH peroxidase, and SOD. The protein content of the cell-free extract was determined according to Bradford using bovine serum albumin as the standard.

\section{$\mathrm{H}_{2} \mathrm{O}_{2}$ Sensitivity Assay}

Sensitivity of the cells to $\mathrm{H}_{2} \mathrm{O}_{2}$ was assayed based on the method reported by Shimamura et al. (1992). Cells were exposed to $10,000 \mathrm{mg} / \mathrm{L}, 20,000 \mathrm{mg} / \mathrm{L}$, and 30,000 $\mathrm{mg} / \mathrm{L}$ of $\mathrm{H}_{2} \mathrm{O}_{2}$ for $1 \mathrm{~min}$. Appropriate dilutions of the cell suspension exposed to $\mathrm{H}_{2} \mathrm{O}_{2}$ were spread plated on MRS agar (Oxoid, Australia). Plates were incubated under anaerobic conditions at $37^{\circ} \mathrm{C}$ for $48 \mathrm{~h}$, and the cell counts were enumerated.

\section{$\mathrm{H}_{2} \mathrm{O}_{2}$ Decomposing Ability}

The ability of the cell pellet to decompose $\mathrm{H}_{2} \mathrm{O}_{2}$ was determined based on method reported by Shimamura et al. (1992). Known amount of cells were incubated anaerobically with $300 \mathrm{nmol} \mathrm{H}_{2} \mathrm{O}_{2}$ at $37^{\circ} \mathrm{C}$ for $1 \mathrm{~h}$. The concentration of residual $\mathrm{H}_{2} \mathrm{O}_{2}$ in the test tube after incubation was estimated by the method described by Marty-Teysset et al. (2000).

\section{Determination of Acetic Acid and Lactic Acid Levels}

The cell-free broth was clarified using Carrez reagents. Five milliliters of Carrez-I-solution [potassium hexacyanoferrate (II), $85 \mathrm{mM}$ ] and $5 \mathrm{ml}$ of Carrez-IIsolution (Zinc sulfate, $250 \mathrm{mM}$ ) were added to $60 \mathrm{ml}$ of distilled water containing $10 \mathrm{ml}$ of the cell free broth. The $\mathrm{pH}$ of the solution was adjusted to 8 using $0.1 \mathrm{~N}$ $\mathrm{NaOH}$, and the volume was made up to $100 \mathrm{ml}$ with distilled water. The solution was mixed with activated charcoal (1\%), agitated and then filtered. The concentrations of lactate and acetate in the clarified broth were determined using commercially available kits 
(Boehringer Mannheim) and used for the calculation of the lactate to acetate ratio in the Bifidobacterium spp.

\section{Enzyme Assays}

Activities of $\mathrm{NADH}$ oxidase and $\mathrm{NADH}$ peroxidase were assayed spectrophotometrically as described by Talwalkar et al. (2003) by measuring the initial linear slope of oxidation of NADH at $340 \mathrm{~nm}$ at $25^{\circ} \mathrm{C}(\varepsilon=6.22$ $\left.M^{-1}, \mathrm{~cm}^{-1}\right)$. The reaction mix contained the cell free extract, NADH $(67 \mu M)$, FAD $(67 \mu M), \mathrm{H}_{2} \mathrm{O}_{2}(1 \mathrm{~m} M)$ and McIlvaine buffer, $\mathrm{pH} 4.5$ to 6.5 in a total volume of $3 \mathrm{ml}$. The $\mathrm{pH}$ of the McIlvaine buffer was adjusted using an inoLAB pH Level 1 meter (WTW Gmbh, Germany). The assay was conducted for $3 \mathrm{~min}$ in the presence as well as in absence of oxygen. NADH oxidase activity was derived from the difference in the slopes. The slope of the anaerobic assay provided the NADH peroxidase units. For both these enzymes, $1 \mathrm{U}$ of activity was defined as the amount that oxidized $1 \mathrm{nmol}$ of $\mathrm{NADH}$ per minute at $25^{\circ} \mathrm{C}$.

SOD was measured based on the method reported by Sun and Zigman (1978). One hundred microliters of epinephrine $(0.1 \mathrm{M})$ was added to $100 \mu \mathrm{l}$ of cell-free extract in 1.9-ml $50 \mathrm{~m} M$ Tris-HCl buffer $(\mathrm{pH} 7.5)$ and the inhibition of epinephrine autooxidation was monitored at $320 \mathrm{~nm}$. One unit of SOD was defined as the amount inhibiting the rate of epinephrine autooxidation by $50 \%$.

The specific activities of NADH oxidase, NADH peroxidase and SOD were calculated by dividing the total enzyme units (EU) by the total protein of the cell free extract.

\section{Statistics}

The means from six replicates were analyzed using single factor ANOVA $(\alpha=0.05)$ MS Excel software. Significant differences among individual means were determined using Tukey's HSD test.

\section{RESULTS}

\section{Levels of Lactic Acid and Lactate-to-Acetate Ratio}

Lactobacillus acidophilus 2400 and L. acidophilus 2409 demonstrated a significant $(P<0.05)$ reduction in the production of lactate as the oxygen in the hypoxic glove box was increased (Table 1). The decrease in lactate levels correlated strongly $\left(\mathrm{r}^{2}=0.9\right)$ with the increase in the oxygen percentage. From 0 to $21 \%$ oxygen, lactate levels in L. acidophilus 2400 decreased $71 \%$ from 6.9 to $2 \mathrm{mg} / \mathrm{ml}$. These levels were similar to those seen in L. acidophilus 2409 in which the lactate produc- tion decreased by $64 \%$. No acetate was detected in the culture broth of either $L$. acidophilus strains.

Levels of lactate followed a similar correlating trend $\left(\mathrm{r}^{2}=0.9\right)$ in the Bifidobacterium spp. (Table 1). Except for B. lactis 1941, in all the other bifidobacteria tested, concentrations of lactate at the various oxygen percentages were significantly different $(P<0.05)$ from each other. In $B$. lactis 1941, no significant reduction $(P>$ 0.05 ) was seen in lactate levels when the oxygen was increased from 15 to $21 \%$. The decrease in lactate, however, varied among the strains. The levels of lactate in B. infantis 1912 dropped sharply by $85 \%$ when the oxygen was increased from 0 to $15 \%$, whereas in $B$. pseudolongum 1944 , lactate levels at 0 and $21 \%$ oxygen differed by only $24 \%$. Interestingly, under anaerobic conditions, lactate levels in B. lactis 1941 and B. pseudolongum 1944 were double to that produced by the oxygen tolerant $B$. longum 55815 . Except for $B$. infantis 1912 , all the other Bifidobacterium spp. tested in this study were able to grow in $21 \%$ oxygen.

The decrease in lactate levels and increased production of acetate in the Bifidobacterium spp. caused significant lowering of the lactate to acetate ratio $(P<$ 0.05) (Table 1.). The decrease in the ratio was strain dependent. As the concentration of oxygen was increased to $21 \%$, the ratio decreased differently in $B$. pseudolongum 1944 and B. longum 55815 even though both strains had a lactate/acetate ratio of 2.5 at $0 \%$ oxygen. While the ratio dropped $36 \%$ in $B$. pseudolongum 1944, it decreased steeply by $98 \%$ in B. longum 55815. Similarly, B. infantis 1912 exhibited a sharp decrease of $82 \%$ in the lactate-to-acetate ratio when the oxygen concentration was increased from $0 \%$ oxygen to $15 \%$ oxygen, whereas there was only a $55 \%$ decrease in B. lactis 1941.

\section{$\mathrm{H}_{2} \mathrm{O}_{2}$ Decomposing Ability}

As the oxygen concentration was increased stepwise from 0 to $21 \%$, except for $B$. pseudolongum 1944, all strains showed a significant $(P<0.05)$ rise in their ability to decompose $\mathrm{H}_{2} \mathrm{O}_{2}$ (Table 2). In B. pseudolongum 1944, no increase in the $\mathrm{H}_{2} \mathrm{O}_{2}$ decomposition capacity was seen when the oxygen was raised from 15 to $21 \%$. In all the strains, the extent of $\mathrm{H}_{2} \mathrm{O}_{2}$ decomposed was observed to be strain dependent. At $21 \%$ oxygen, while the $\mathrm{H}_{2} \mathrm{O}_{2}$ decomposing ability of $B$. lactis 1941 was 11 times higher than that observed at $0 \%$ oxygen, in L. acidophilus 2409 it was found to increase by $73 \%$. When grown in similar concentrations of oxygen, the $\mathrm{H}_{2} \mathrm{O}_{2}$ decomposing ability of $L$. acidophilus strains was at least twice of that seen in the Bifidobacterium spp. At $0 \%$ oxygen, the $\mathrm{H}_{2} \mathrm{O}_{2}$ decomposing ability of $B$. longum 55815 was almost seven times that of $B$. pseudolongum 
Table 1. Effect of different oxygen concentrations on the lactic acid produced by Lactobacillus acidophilus strains and on the lactate to acetate ratio in Bifidobacterium spp. ${ }^{\mathrm{A}}$.

\begin{tabular}{|c|c|c|c|}
\hline Strain & \% Oxygen & $\begin{array}{l}\text { Lactic acid } \\
(\mathrm{mg} / \mathrm{ml})^{\mathrm{B}}\end{array}$ & Lactate/Acetate \\
\hline L. acidophilus $2400^{1}$ & $\begin{array}{r}0 \\
5 \\
10 \\
15 \\
21\end{array}$ & $\begin{array}{l}6.9 \\
5.8 \\
4.6 \\
2.3 \\
2.0\end{array}$ & $\begin{array}{l}\cdots \\
\cdots \\
\cdots \\
\cdots\end{array}$ \\
\hline L. acidophilus $2409^{2}$ & $\begin{array}{r}0 \\
5 \\
10 \\
15 \\
21\end{array}$ & $\begin{array}{l}6.5 \\
5.8 \\
4.3 \\
2.8 \\
2.3\end{array}$ & $\begin{array}{l}\ldots \\
\ldots \\
\ldots \\
\ldots\end{array}$ \\
\hline B. infantis $1912^{3}$ & $\begin{array}{r}0 \\
5 \\
10 \\
15\end{array}$ & $\begin{array}{r}11.2 \\
4.3 \\
4.0 \\
1.6\end{array}$ & $\begin{array}{l}4.1 \\
1.8 \\
1.7 \\
0.7\end{array}$ \\
\hline B. lactis $1941^{4}$ & $\begin{array}{r}0 \\
5 \\
10 \\
15 \\
21\end{array}$ & $\begin{array}{c}13.0 \\
8.1 \\
7.6 \\
5.5^{\mathrm{a}} \\
5.2^{\mathrm{a}}\end{array}$ & $\begin{array}{l}5.9 \\
4.5 \\
3.8 \\
2.9 \\
2.6\end{array}$ \\
\hline B. pseudolongum $1944^{5}$ & $\begin{array}{r}0 \\
5 \\
10 \\
15 \\
21\end{array}$ & $\begin{array}{r}10.5 \\
9.4 \\
9.1 \\
8.2 \\
7.9\end{array}$ & $\begin{array}{l}2.5 \\
2.3 \\
2.2 \\
1.9 \\
1.5\end{array}$ \\
\hline B. longum $55815^{6}$ & $\begin{array}{r}0 \\
5 \\
10 \\
15 \\
21\end{array}$ & $\begin{array}{l}5.0 \\
3.1 \\
2.1 \\
0.7 \\
0.1\end{array}$ & $\begin{array}{l}2.5 \\
2.1 \\
1.7 \\
0.3 \\
0.05\end{array}$ \\
\hline
\end{tabular}

\footnotetext{
${ }^{\mathrm{A}}$ Mean $(\mathrm{n}=6)$.

B 1,2,3,4,5,6 Standard error of least square means $=0.07,0.05,0.007,0.07,0.08$, and 0.02 , respectively; ( $\mathrm{df}$ $=25)^{1,2,4,5,6},(\mathrm{df}=20)^{3}$.

${ }^{\mathrm{C} 3,4,5,6}$ Standard error of least square means $=0.007,0.04,0.02$, and 0.03 , respectively; $(\mathrm{df}=25)^{4,5,6}$, (df $=20)^{3}$.

${ }^{\mathrm{a}}$ Means in columns with common subscript do not differ significantly $(P>0.05)$.
}

1944. The $\mathrm{H}_{2} \mathrm{O}_{2}$ decomposing ability in L. acidophilus 2400 and $B$. longum 55815 at $21 \%$ oxygen was almost double to that observed when they were grown under $0 \%$ oxygen.

\section{Sensitivity to $\mathrm{H}_{2} \mathrm{O}_{2}$}

In all the probiotic strains tested in this study, exposure to $10,000,20,000$, and $30,000 \mathrm{mg} / \mathrm{L}$ of $\mathrm{H}_{2} \mathrm{O}_{2}$ did not cause any significant decrease $(P>0.05)$ in the cell counts (Table 3). Moreover, this trend did not change even when cells were grown in the different oxygen concentrations.

\section{NADH Oxidase and NADH Peroxidase Activities}

In both $L$. acidophilus as well as Bifidobacterium spp., the $\mathrm{pH}$ profiles of $\mathrm{NADH}$ oxidase (Figure 1) and NADH peroxidase (Figure 2 ) revealed maximal activity at $\mathrm{pH} 5.0$ and it remained unchanged even when cells were grown in different oxygen environments.

Except in B. infantis 1912, in all other strains, the specific activities of intracellular NADH oxidase and NADH peroxidase at $21 \%$ oxygen were significantly higher $(P<0.05)$ than those observed at $0 \%$ oxygen (Table 2). In $B$. infantis 1912, NADH oxidase units increased significantly $(P<0.05)$ when oxygen was increased from 0 to $5 \%$, but no further increase was seen when it was grown in 10 and $15 \%$ oxygen. Similarly, the specific activity of NADH peroxidase increased significantly $(P<0.05)$ when the oxygen was increased from 0 to $5 \%$, but no significant change $(P>0.05)$ was seen in its specific activity when oxygen was further increased to 10 and 15\% (Table 2). In anaerobic conditions ( $0 \%$ oxygen), the specific activity of NADH oxidase and NADH peroxidase in $L$. acidophilus strains were at least 1.6 times higher than in the Bifidobacterium spp. Among the bifidobacteria, B. longum 55815 had 
Table 2. Effect of different oxygen concentrations on the specific activities of NADH oxidase, NADH peroxidase, and superoxide dismutase (SOD) and on the $\mathrm{H}_{2} \mathrm{O}_{2}$ decomposing ability of Lactobacillus acidophilus strains and Bifidobacterium spp.

\begin{tabular}{|c|c|c|c|c|c|}
\hline Strain & $\begin{array}{l}\% \\
\text { Oxygen }\end{array}$ & $\begin{array}{l}\text { NADH } \\
\text { oxidase }^{A}\end{array}$ & $\begin{array}{l}\mathrm{NADH} \\
\text { peroxidase }^{\mathrm{B}}\end{array}$ & S.O.D. ${ }^{\mathrm{C}}$ & $\begin{array}{l}{\text { nmol } \mathrm{H}_{2} \mathrm{O}_{2}}_{\text {decomposed }^{\mathrm{D}}}\end{array}$ \\
\hline L. acidophilus $2400^{1}$ & $\begin{array}{r}0 \\
5 \\
10 \\
15 \\
21\end{array}$ & $\begin{array}{l}20.62 \\
25.38^{\mathrm{a}} \\
25.64^{\mathrm{a}} \\
26.44^{\mathrm{a}, \mathrm{b}} \\
27.26^{\mathrm{b}}\end{array}$ & $\begin{array}{l}18.37 \\
22.86^{\mathrm{a}} \\
23.87^{\mathrm{a}, \mathrm{b}} \\
25.18^{\mathrm{b}} \\
25.28\end{array}$ & $\begin{array}{l}1.10^{\mathrm{a}} \\
1.06^{\mathrm{a}} \\
1.02^{\mathrm{a}, \mathrm{b}} \\
1.00^{\mathrm{a}, \mathrm{b}} \\
0.94^{\mathrm{b}}\end{array}$ & \begin{tabular}{l|l}
17.4 & \\
18.7 & \\
28.4 & \\
32.4 & \\
38.4 &
\end{tabular} \\
\hline L. acidophilus $2409^{2}$ & $\begin{array}{r}0 \\
5 \\
10 \\
15 \\
21\end{array}$ & $\begin{array}{l}21.09^{\mathrm{a}} \\
21.85^{\mathrm{a}, \mathrm{b}} \\
21.94^{\mathrm{a}, \mathrm{b}} \\
23.05^{\mathrm{b}} \\
25.21\end{array}$ & $\begin{array}{l}20.20^{\mathrm{a}} \\
21.06^{\mathrm{a}, \mathrm{b}} \\
22.29^{\mathrm{b}} \\
23.87 \\
25.65\end{array}$ & $\begin{array}{l}1.64^{\mathrm{a}} \\
1.58^{\mathrm{a}} \\
1.35^{\mathrm{b}} \\
1.30^{\mathrm{b}} \\
1.36^{\mathrm{b}}\end{array}$ & $\begin{array}{l}20.3 \\
22.3 \\
28.5 \\
33.7 \\
35.2\end{array}$ \\
\hline B. infantis $1912^{3}$ & $\begin{array}{r}0 \\
5 \\
10 \\
15\end{array}$ & $\begin{array}{l}2.10 \\
4.67^{\mathrm{a}} \\
4.38^{\mathrm{a}} \\
4.66^{\mathrm{a}}\end{array}$ & $\begin{array}{l}5.35 \\
6.46 \\
7.67^{\mathrm{a}} \\
7.56^{\mathrm{a}}\end{array}$ & $\begin{array}{l}0.86^{\mathrm{a}} \\
1.02^{\mathrm{a}} \\
1.58 \\
1.30^{\mathrm{a}}\end{array}$ & $\begin{array}{l}2.69 \\
4.72 \\
5.42 \\
5.48\end{array}$ \\
\hline B. lactis $1941^{4}$ & $\begin{array}{r}0 \\
5 \\
10 \\
15 \\
21\end{array}$ & $\begin{array}{l}4.97^{\mathrm{a}} \\
5.37^{\mathrm{a}} \\
6.50^{\mathrm{b}} \\
7.05^{\mathrm{b}} \\
7.32^{\mathrm{b}}\end{array}$ & $\begin{array}{r}5.32 \\
6.35 \\
7.68 \\
8.65 \\
10.53\end{array}$ & $\begin{array}{l}1.36 \\
2.03^{\mathrm{a}} \\
2.10^{\mathrm{a}} \\
1.90^{\mathrm{a}} \\
1.19\end{array}$ & $\begin{array}{l}0.78 \\
1.16 \\
4.27 \\
7.99 \\
8.87\end{array}$ \\
\hline B. pseudolongum $1944^{5}$ & $\begin{array}{r}0 \\
5 \\
10 \\
15 \\
21\end{array}$ & $\begin{array}{l}1.99^{\mathrm{a}} \\
2.2^{\mathrm{a}} \\
3.2 \\
5.2 \\
6.2\end{array}$ & $\begin{array}{l}3.47 \\
4.08^{\mathrm{a}} \\
4.19^{\mathrm{a}} \\
4.30^{\mathrm{a}} \\
6.07\end{array}$ & $\begin{array}{l}0.86^{\mathrm{a}} \\
0.65^{\mathrm{b}} \\
0.81^{\mathrm{a}} \\
0.70^{\mathrm{b}} \\
0.57^{\mathrm{b}}\end{array}$ & $\begin{array}{l}1.05 \\
1.34 \\
3.29 \\
3.71^{\mathrm{a}} \\
3.71^{\mathrm{a}}\end{array}$ \\
\hline B. longum $55815^{6}$ & $\begin{array}{r}0 \\
5 \\
10 \\
15 \\
21\end{array}$ & $\begin{array}{l}12.74 \\
14.57 \\
15.97 \\
18.11^{\mathrm{a}} \\
18.91^{\mathrm{a}}\end{array}$ & $\begin{array}{l}10.37 \\
12.38 \\
16.40^{\mathrm{a}} \\
16.86^{\mathrm{a}} \\
16.86^{\mathrm{a}}\end{array}$ & $\begin{array}{l}2.71^{\mathrm{a}} \\
2.89^{\mathrm{a}} \\
2.66^{\mathrm{a}} \\
2.36^{\mathrm{b}} \\
2.52^{\mathrm{a}, \mathrm{b}}\end{array}$ & $\begin{array}{r}6.97 \\
7.87 \\
8.28 \\
10.07 \\
13.32\end{array}$ \\
\hline
\end{tabular}

a,b,c Means in columns with like superscripts do not differ significantly $(P>0.05)$. Means in columns with no superscripts differ significantly $(P<0.05)$

A,B,C Expressed as Enzyme Units/per mg of total protein of the cell free extract.

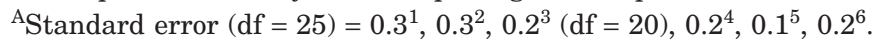

${ }^{\mathrm{B}}$ Standard error $(\mathrm{df}=25)=0.3^{1}, 0.3^{2}, 0.1^{3}(\mathrm{df}=20), 0.1^{4}, 0.1^{5}, 0.2^{6}$.

${ }^{\mathrm{C}}$ Standard error $(\mathrm{df}=25)=0.02^{1}, 0.03^{2}, 0.1^{3}(\mathrm{df}=20), 0.05^{4}, 0.02^{5}, 0.05^{6}$.

${ }^{\mathrm{D}}$ Expressed as nmol $\mathrm{H}_{2} \mathrm{O}_{2}$ decomposed per $10^{9} \mathrm{cfu}$.

${ }^{\mathrm{D}}$ Standard error $(\mathrm{df}=25)=0.2^{1}, 0.07^{2}, 0.01^{3}(\mathrm{df}=20), 0.03^{4}, 0.07^{5}, 0.01^{6}$.

the highest concentrations of $\mathrm{NADH}$ oxidase and $\mathrm{NADH}$ peroxidase, although no significant increase $(P>0.05)$ was observed in the enzyme concentrations after increasing the percentage of oxygen from 15 to $21 \%$. In B. infantis 1912 , B. lactis 1941, and L. acidophilus 2409 , the concentrations of $\mathrm{NADH}$ peroxidase were found to correlate strongly $\left(\mathrm{r}^{2}=0.9\right)$ with their $\mathrm{H}_{2} \mathrm{O}_{2}$ decomposing ability (Table 2).

\section{SOD Activity}

Concentrations of SOD failed to demonstrate any conclusive trend with the various oxygen percentages, although it was detected in every strain (Table 2). In contrast to the increasing concentrations of NADH oxidase and NADH peroxidase, the concentrations of SOD were uncorrelated $\left(\mathrm{r}^{2}<0.9\right)$. Among all the strains, however, B. longum 55815 had the highest intracellular concentrations of SOD.

\section{DISCUSSION}

Oxygen plays a critical role in the metabolism of bifidobacteria and L. acidophilus (Condon, 1987). Although these strains are categorized as anaerobes and microaerophilic, respectively (Hammes and Vogel, 1995; Sgorbati et al., 1995), in our study, except for $B$. infantis 1912, all remaining strains were able to grow well at $21 \%$ oxygen. This was unexpected as bifidobacteria are classified as strict anaerobes, suggesting that these particular strains possessed a mechanism to overcome the deleterious effects of oxygen toxicity. Results demonstrated that growth under the various oxygen concentrations clearly altered the metabolic and bio- 
Table 3. Effect of exposure to $\mathrm{H}_{2} \mathrm{O}_{2}$ on the survival $\left(\log _{10} \mathrm{cfu} / \mathrm{ml}\right)$ of Lactobacillus acidophilus strains and Bifidobacterium spp. grown in different oxygen concentrations.

\begin{tabular}{|c|c|c|c|c|c|}
\hline \multirow[b]{2}{*}{ Strain } & \multirow[b]{2}{*}{$\%$ Oxygen } & \multicolumn{4}{|c|}{$\mathrm{H}_{2} \mathrm{O}_{2}(\mathrm{mg} / \mathrm{kg})$} \\
\hline & & 0 & 10,000 & 20,000 & 30,000 \\
\hline L. acidophilus 2400 & $\begin{array}{r}0 \\
5 \\
10 \\
15 \\
21\end{array}$ & $\begin{array}{l}9.7^{\mathrm{a}} \\
9.8^{\mathrm{a}} \\
9.7^{\mathrm{a}} \\
9.5^{\mathrm{a}} \\
9.8^{\mathrm{a}}\end{array}$ & $\begin{array}{l}9.7^{\mathrm{a}} \\
9.8^{\mathrm{a}} \\
9.7^{\mathrm{a}} \\
9.5^{\mathrm{a}} \\
9.8^{\mathrm{a}}\end{array}$ & $\begin{array}{l}9.7^{\mathrm{a}} \\
9.8^{\mathrm{a}} \\
9.7^{\mathrm{a}} \\
9.5^{\mathrm{a}} \\
9.8^{\mathrm{a}}\end{array}$ & $\begin{array}{l}9.7^{\mathrm{a}} \\
9.8^{\mathrm{a}} \\
9.7^{\mathrm{a}} \\
9.5^{\mathrm{a}} \\
9.8^{\mathrm{a}}\end{array}$ \\
\hline L. acidophilus 2409 & $\begin{array}{r}0 \\
5 \\
10 \\
15 \\
21\end{array}$ & $\begin{array}{l}9.9^{\mathrm{a}} \\
9.6^{\mathrm{a}} \\
9.8^{\mathrm{a}} \\
9.8^{\mathrm{a}} \\
9.9^{\mathrm{a}}\end{array}$ & $\begin{array}{l}9.9^{\mathrm{a}} \\
9.6^{\mathrm{a}} \\
9.8^{\mathrm{a}} \\
9.8^{\mathrm{a}} \\
9.9^{\mathrm{a}}\end{array}$ & $\begin{array}{l}9.9^{\mathrm{a}} \\
9.6^{\mathrm{a}} \\
9.8^{\mathrm{a}} \\
9.8^{\mathrm{a}} \\
9.9^{\mathrm{a}}\end{array}$ & $\begin{array}{l}9.9^{\mathrm{a}} \\
9.6^{\mathrm{a}} \\
9.8^{\mathrm{a}} \\
9.8^{\mathrm{a}} \\
9.9^{\mathrm{a}}\end{array}$ \\
\hline B. infantis 1912 & $\begin{array}{r}0 \\
5 \\
10 \\
15\end{array}$ & $\begin{array}{l}9.9^{\mathrm{a}} \\
9.7^{\mathrm{a}} \\
9.9^{\mathrm{a}} \\
9.5^{\mathrm{a}}\end{array}$ & $\begin{array}{l}9.9^{\mathrm{a}} \\
9.7^{\mathrm{a}} \\
9.9^{\mathrm{a}} \\
9.5^{\mathrm{a}}\end{array}$ & $\begin{array}{l}9.9^{\mathrm{a}} \\
9.7^{\mathrm{a}} \\
9.9^{\mathrm{a}} \\
9.5^{\mathrm{a}}\end{array}$ & $\begin{array}{l}9.9^{\mathrm{a}} \\
9.7^{\mathrm{a}} \\
9.9^{\mathrm{a}} \\
9.5^{\mathrm{a}}\end{array}$ \\
\hline B. lactis 1941 & $\begin{array}{r}0 \\
5 \\
10 \\
15 \\
21\end{array}$ & $\begin{array}{l}9.9^{\mathrm{a}} \\
9.7^{\mathrm{a}} \\
9.8^{\mathrm{a}} \\
9.6^{\mathrm{a}} \\
9.8^{\mathrm{a}}\end{array}$ & $\begin{array}{l}9.9^{\mathrm{a}} \\
9.7^{\mathrm{a}} \\
9.8^{\mathrm{a}} \\
9.7^{\mathrm{a}} \\
9.8^{\mathrm{a}}\end{array}$ & $\begin{array}{l}9.9^{\mathrm{a}} \\
9.7^{\mathrm{a}} \\
9.8^{\mathrm{a}} \\
9.7^{\mathrm{a}} \\
9.8^{\mathrm{a}}\end{array}$ & $\begin{array}{l}9.9^{\mathrm{a}} \\
9.7^{\mathrm{a}} \\
9.8^{\mathrm{a}} \\
9.7^{\mathrm{a}} \\
9.8^{\mathrm{a}}\end{array}$ \\
\hline B. pseudolongum 1944 & $\begin{array}{r}0 \\
5 \\
10 \\
15 \\
21\end{array}$ & $\begin{array}{l}9.5^{\mathrm{a}} \\
9.6^{\mathrm{a}} \\
9.7^{\mathrm{a}} \\
9.7^{\mathrm{a}} \\
9.9^{\mathrm{a}}\end{array}$ & $\begin{array}{l}9.5^{\mathrm{a}} \\
9.6^{\mathrm{a}} \\
9.7^{\mathrm{a}} \\
9.7^{\mathrm{a}} \\
9.9^{\mathrm{a}}\end{array}$ & $\begin{array}{l}9.5^{\mathrm{a}} \\
9.6^{\mathrm{a}} \\
9.7^{\mathrm{a}} \\
9.7^{\mathrm{a}} \\
9.9^{\mathrm{a}}\end{array}$ & $\begin{array}{l}9.5^{\mathrm{a}} \\
9.6^{\mathrm{a}} \\
9.7^{\mathrm{a}} \\
9.7^{\mathrm{a}} \\
9.9^{\mathrm{a}}\end{array}$ \\
\hline B. longum 55815 & $\begin{array}{r}0 \\
5 \\
10 \\
15 \\
21\end{array}$ & $\begin{array}{l}9.7^{\mathrm{a}} \\
9.9^{\mathrm{a}} \\
9.8^{\mathrm{a}} \\
9.5^{\mathrm{a}} \\
9.8^{\mathrm{a}}\end{array}$ & $\begin{array}{l}9.7^{\mathrm{a}} \\
9.9^{\mathrm{a}} \\
9.8^{\mathrm{a}} \\
9.5^{\mathrm{a}} \\
9.8^{\mathrm{a}}\end{array}$ & $\begin{array}{l}9.7^{\mathrm{a}} \\
9.9^{\mathrm{a}} \\
9.8^{\mathrm{a}} \\
9.5^{\mathrm{a}} \\
9.8^{\mathrm{a}}\end{array}$ & $\begin{array}{l}9.7^{\mathrm{a}} \\
9.9^{\mathrm{a}} \\
9.8^{\mathrm{a}} \\
9.5^{\mathrm{a}} \\
9.8^{\mathrm{a}}\end{array}$ \\
\hline
\end{tabular}

${ }^{\mathrm{a}}$ Means $(\mathrm{n}=6)$ in rows with common superscripts do not differ significantly $(P>0.05)$.

chemical behavior in both L. acidophilus and Bifidobacterium spp.

Lactate and acetate are the main end products of fermentation in lactic acid bacteria. While L. acidophilus converts glucose to lactic acid via a homolactic fermentation (Hammes and Vogel, 1995), bifidobacteria convert two moles of glucose to form 3 moles of acetate and 2 moles of lactate (Sgorbati et al., 1995). When this molar ratio is expressed in milligrams per milliliter, a theoretical ratio of 1 is obtained and can serve as an index of the metabolic activity of the cell. The absence of acetate in the culture broths of $L$. acidophilus 2400 and L. acidophilus 2409 even during aerobic growth confirmed their obligate homolactic fermentation.

Condon (1987) suggested that in anaerobic conditions, lactic acid bacteria convert pyruvate to lactate by the NADH-dependent lactate dehydrogenase, regenerating $\mathrm{NAD}^{+}$needed for the dehydrogenation reactions of sugar metabolism. In the presence of oxygen, however, the pyruvate metabolism can be altered by the competition of $\mathrm{NADH}$ oxidases and $\mathrm{NADH}$ peroxidases with lactate dehydrogenase for NADH affecting the fermentation end products. This provides clues to the met- abolic changes observed in $L$. acidophilus 2400 and $L$. acidophilus 2409 when grown under increasing concentrations of oxygen. Smart and Thomas (1987) proposed that in lactic anaerobic streptococci, the regeneration of $\mathrm{NAD}^{+}$by the activities of NADH oxidase: NADH peroxidase system could remove the need for conversion of pyruvate to lactate, resulting in lower lactate production. A mechanism similar to that observed in lactic streptococci may be responsible for the increase in the specific activities of NADH oxidase and NADH peroxidase and the simultaneous decrease in the lactate levels in L. acidophilus 2400 and L. acidophilus 2409. Apart from the enzyme activities, it is also probable that the decrease in lactate production in these lactobacilli was because of less growth of the cells caused by the increase in oxygen concentration.

In a study conducted on B. lactis, Meile et al. (1997) reported a high acetate/lactate ratio when the strain was grown anaerobically, and this ratio was found to decrease in the presence of oxygen. The four Bifidobacterium spp. tested in our study, however, gave contrary results. As seen in Table 1, levels of lactic acid in bifidobacteria strains were highest when they were 

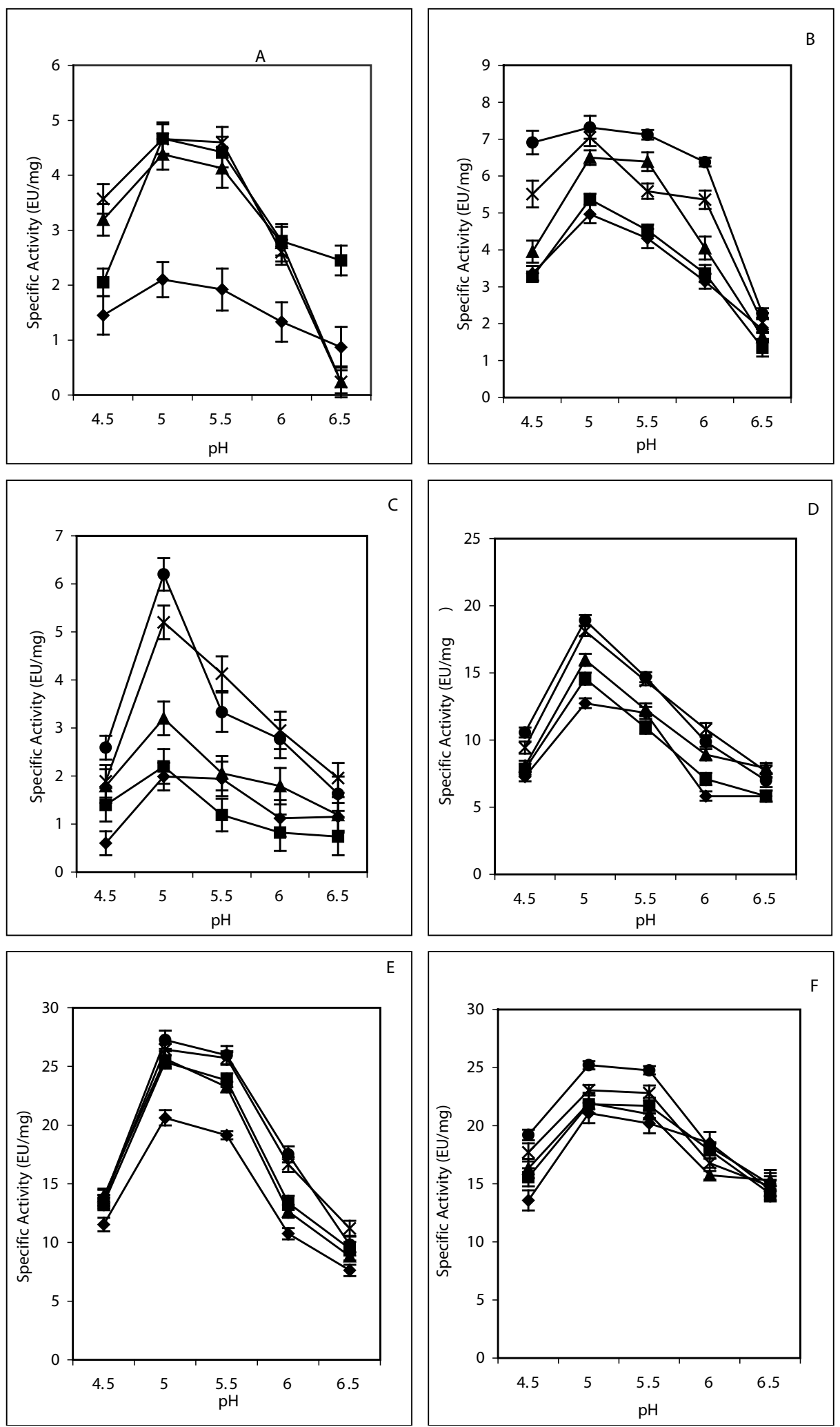

Figure 1. $\mathrm{pH}$ profile of reduced NAD oxidase of (A) Bifidobacterium infantis 1912, (B) Bifidobacterium lactis 1941, (C) Bifidobacterium pseudolongum 1944, (D) Bifidobacterium longum 55815, (E) Lactobacillus acidophilus 2400, and (F) L. acidophilus 2409 under different oxygen concentrations: (- -$) 0 \%,(-\square-) 5 \%,(-\mathbf{\Delta}-) 10 \%,(\mathbf{x}-) 15 \%,(-\bullet-) 21 \%$. 

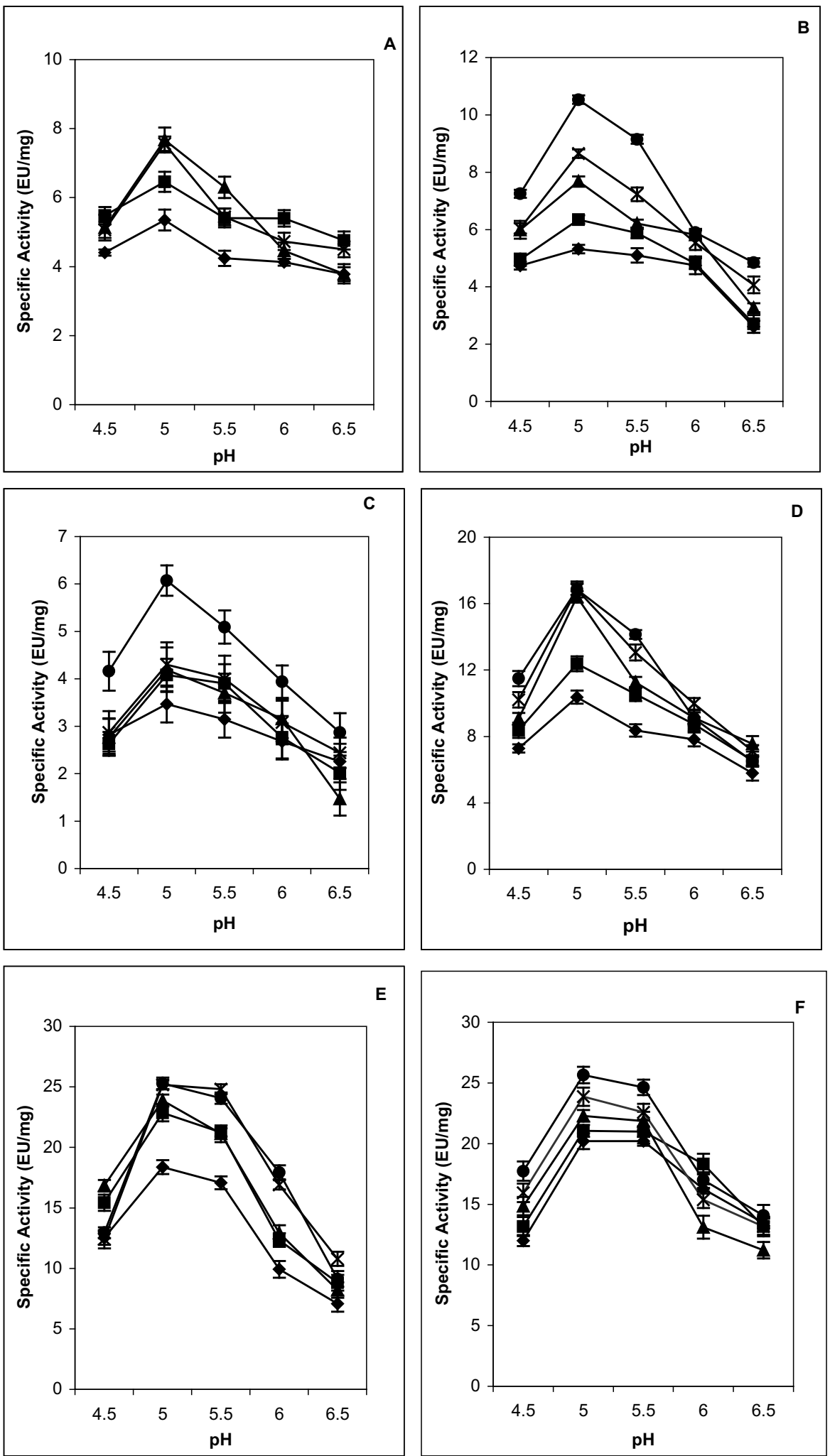

Figure 2. $\mathrm{pH}$ profile of reduced NAD peroxidase of (A) Bifidobacterium infantis 1912, (B) Bifidobacterium lactis 1941, (C) Bifidobacterium pseudolongum 1944, (D) Bifidobacterium longum 55815, (E) Lactobacillus acidophilus 2400, and (F) Lactobacillus acidophilus 2409 under different oxygen concentrations: (- -) $0 \%,(-\mathbf{-}) 5 \%,(-\mathbf{\Delta - )} 10 \%,(-\mathbf{x}-) 15 \%,(-\bullet-) 21 \%$. 
grown anaerobically. With increase in oxygen concentrations, however, the lactate levels dropped, while acetate levels increased, reducing the lactate-to-acetate ratio. Interestingly, this closely resembles the lactateacetate production patterns seen in other lactic acid bacteria such as lactic streptococci. Smart and Thomas (1987) found that aeration increased the pyruvate dehyrogenase in lactic streptococci, whereas lactate dehydrogenase activities decreased suggesting that aerobically, cells are more suited to produce acetate. This could explain the decrease in lactate levels and the subsequent increase in acetate production in our Bifidobacterium spp. when they were grown aerobically.

In earlier studies on bifidobacteria, concentrations of $\mathrm{NADH}$ oxidase and NADH peroxidase have been found to correlate with oxygen tolerance (Shimamura et al., 1992; Ahn et al., 2001). The limited knowledge about the $\mathrm{pH}$ optima of intracellular $\mathrm{NADH}$ oxidases and NADH peroxidases of bifidobacteria as well as the absence of a standard assay may, however, have led to inaccurate estimations of NADH oxidases in Bifidobacterium spp. (Talwalkar et al., 2003). The NADH oxidases and NADH peroxidases of bifidobacteria were assayed at neutral $\mathrm{pH}$ by de Vries and Stouthamer (1969) and Uesugi and Yajima (1978). Our study, however, revealed that maximum activity of these enzymes was at $\mathrm{pH}$ 5.0. The $\mathrm{pH}$ optima of the NADH oxidases and NADH peroxidases of our Bifidobacterium spp. agreed with the findings of Shimamura et al. (1992). The NADH oxidase: NADH peroxidase system has not been studied in L. acidophilus so far and we therefore suggest that in L. acidophilus strains, these enzymes be assayed at $\mathrm{pH} 5$ to ensure maximal activity.

Additionally, the consistency of the optimum $\mathrm{pH}$ across the different oxygen concentrations in the Bifidobacterium spp. and $L$. acidophilus strains suggests that oxygen does not affect the $\mathrm{pH}$ profiles of their NADH oxidases and NADH peroxidases. The high specific activity of both NADH oxidase and NADH peroxidase in $L$. acidophilus strains and oxygen tolerant $B$. longum 55815 (Table 2) highlight the role they play in aerotolerance. The inability of $B$. infantis 1912 to increase its NADH oxidase activity seems to have resulted in its failure to grow at $21 \%$ oxygen. The strong correlation between these enzymes and the different oxygen concentrations suggests that these enzymes are inducible with oxygen acting as an inducer. These findings are similar to those seen in lactic streptococci (Higuchi, 1984; Smart and Thomas, 1987), in which the activities of NADH oxidase and $\mathrm{NADH}$ peroxidase increased when strains were exposed to oxygen.

$\mathrm{NADH}$ peroxidase activities correlated well $\left(\mathrm{r}^{2} \geq 0.9\right)$ with the $\mathrm{H}_{2} \mathrm{O}_{2}$ decomposition in all the strains, underpinning this enzyme's relevance in protecting the cell from the lethal effects of intracellular accumulation of $\mathrm{H}_{2} \mathrm{O}_{2}$.

Bifidobacteria have been found to differ in their sensitivities to $\mathrm{H}_{2} \mathrm{O}_{2}$ and in their ability to decompose $\mathrm{H}_{2} \mathrm{O}_{2}$ )de Vries and Stouthamer, 1969; Lim et al., 1998). Shimamura et al. (1992) had reported variation in the $\mathrm{H}_{2} \mathrm{O}_{2}$ sensitivity of four Bifidobacterium spp. with $B$. infantis being the least sensitive to $\mathrm{H}_{2} \mathrm{O}_{2}$. In our study, however, none of the L. acidophilus and Bifidobacterium spp. revealed any significant decrease in cell viability, even after exposure to high concentrations of $30,000 \mathrm{mg} / \mathrm{L}$ $\mathrm{H}_{2} \mathrm{O}_{2}$. This is in contrast to Shimamura et al. (1992), where exposure to $10,000 \mathrm{mg} / \mathrm{L} \mathrm{H}_{2} \mathrm{O}_{2}$ caused significant losses in the viability of three Bifidobacterium spp. strains. Lim et al. (1998) used longer $\mathrm{H}_{2} \mathrm{O}_{2}$ exposure times than those reported in Shimamura et al. (1992), and found a significant decrease in cell viability. It seems likely that the levels of NADH peroxidase in our strains were sufficient to protect them from the short exposure to $\mathrm{H}_{2} \mathrm{O}_{2}$. The increase in the intracellular levels of NADH peroxidase may have also contributed to the $\mathrm{H}_{2} \mathrm{O}_{2}$ sensitivity pattern remaining unchanged over the different oxygen environments.

Anaerobes including lactic acid bacteria usually possess SOD for scavenging toxic oxygen radicals. Previous studies on the SOD of bifidobacteria and L. acidophilus strains have found no correlation between its specific activity and the aerobic environment (Shimamura et al., 1992; Soon-Young and Park, 1997; Lin and Yen, 1999). Results obtained in this study were in accordance with these findings. Although all strains possessed SOD, no conclusive trend could be detected with the oxygen concentration suggesting that oxygen did not seem to induce SOD. Jenny et al. (1999) proposed the role of a superoxide reductase that is independent of SOD and catalase, to detoxify oxygen in anaerobes. Superoxide reductase was not tested in this study and therefore its presence and role in the oxygen tolerance in our test strains cannot be ruled out.

Oxygen tolerance in bifidobacteria and L. acidophilus remains poorly studied. Oxidative stress protein and changes in cellular morphology have been detected in a Bifidobacterium spp., when it was exposed to oxygen (Ahn et al., 2001). The presence of a ferroxidase in bifidobacteria and iron chelation activity in L. acidophilus and strains of Bifidobacterium spp. (Kot et al., 1994; Kim et al., 2001) may be instrumental in protecting cells from peroxide by an iron sequestering mechanism (Yamamoto et al., 2000). Additionally, it has been suggested that bacteria can exhibit a common stress response offering cross protection against a variety of environmental factors (Kim et al., 2001). Our study indicates that an oxidative response is clearly triggered in these strains. The complexity of the oxida- 
tive stress response in bifidobacteria and L. acidophilus could therefore involve a concerted action by a number of individual components interacting with each other to bring about a common stress response.

This study hence offers valuable information for understanding the precise details of the oxidative stress response in L. acidophilus and Bifidobacterium spp. It is hoped that the knowledge gained would be useful for developing techniques to prevent oxygen toxicity in probiotic bacteria. This will ultimately help in the extended survival of probiotic bacteria in dairy foods, thereby ensuring maximum therapeutic benefits to the consumer.

\section{ACKNOWLEDGMENTS}

We would like to express our sincere thanks to Lucille Cussenot and Sidsel Kristensen for providing laboratory assistance during this study. This research was supported by Australian Research Council (SPIRT) and Dairy Farmers, Australia.

\section{REFERENCES}

Ahn, J. B., H. J. Hwang, and J. H. Park. 2001. Physiological responses of oxygen-tolerant anaerobic Bifidobacterium longum under oxygen. J. Microbiol. Biotechnol. 11:443-451.

Archibald, F. S., and I. Fridovich. 1981. Manganese, superoxide dismutase, and oxygen tolerance in some lactic acid bacteria. J. Bacteriol. 146:928-936.

Bradford, M. M. 1976. A rapid and sensitive method for the quantification of microgram quantities of protein utilizing the principle of dye-binding. Anal. Biochem. 72:248-254.

Brunner, J. C., H. Spillmanns, and Z. Puhan. 1993. Changes in pH, free sulphydryl groups, oxygen and redox potential during fermentation of milk with Bifidobacterium longum. Milchwirtschaftliche-Forschung 22:26-31.

Cheng, R., and W. E. Sandine. 1989. Growth characteristics of bifidobacteria species in whey base medium. J. Dairy Sci. 72:148 (Abstr.).

Condon, S. 1987. Responses of lactic acid bacteria to oxygen. FEMS Microbiol. Rev. 46:269-281.

Dave, R. I., and N. P. Shah. 1997. Viability of yoghurt and probiotic bacteria in yoghurts made from commercial starter cultures. Int. Dairy J. 7:31-41.

de Vries, W., and A. H. Stouthamer. 1969. Factors determining the degree of anaerobiosis of Bifidobacterium strains. Arch. Mikrobiol. 65:275-287.

Hammes, W. P., and R. F. Vogel. 1995. The genus Lactobacillus. Pages 19-54 in The Genera of Lactic Acid Bacteria. B. J. B. Wood and W. H. Holzapfel, eds. Blackie Academic, London.

Higuchi, M. 1984. The effect of oxygen on the growth and mannitol fermentation of Streptococcus mutans. J. Gen. Microbiol. 130:1819-1826.

IDF. 1992. General standard of identity for fermented milks. Int. Dairy Fed. 163.

Jenny, F. E. J., M. F. J. M. Verhagen, X. Cui, and M. W. W. Adams. 1999. Anaerobic microbes: Oxygen detoxification without superoxide dismutase. Science 286:306-309.
Kailasapathy, K., and J. Chin. 2000. Survival and therapeutic potential of probiotic organisms with reference to Lactobacillus acidophilus and Bifidobacterium spp. Immunol. Cell Biol. 78:80-88.

Kim, W. S., L. Perl, J. H. Park, J. E. Tandianus, and N. W. Dunn. 2001. Assessment of stress response of the probiotic Lactobacillus acidophilus. Curr. Microbiol. 43:346-350.

Klaver, F. A. M., F. Kingma, and A. H. Weerkamp. 1993. Growth and survival of bifidobacteria in milk. Neth. Milk Dairy J. 47:151-164.

Kot, E., G. Haloftis, and A. Bezkorovainy. 1994. Iron accumulation by Bifidobacteria at low $\mathrm{pO}_{2}$ and in air: Action of putative ferroxidase. J. Agric. Food Chem. 42:685-688.

Kurmann, J. A., and J. L. Rasic. 1991. The health potential of products containing bifidobacteria. Pages 117-158 in Therapeutic Properties of Fermented Milks. R. K. Robinson, ed. Elsevier, London.

Lim, N.-K., J.-C. Yoo, H.-K. Park, T.-R. Heo, and J.-S. So. 1998. The relationship between cell surface hydrophobicity (CSH) and stress tolerance in Bifidobacterium spp. Food Sci. Biotechnol. 7:66-70.

Lin, M. Y., and C. L. Yen. 1999. Antioxidative ability of lactic acid bacteria. J. Agric. Food Chem. 47:1460-1466.

Lourens-Hattingh, A., and B. C. Viljoen. 2001. Yoghurt as probiotic carrier food. Int. Dairy J. 11:1-17.

Marty-Teysset, C., F. de la Torre, and J. R. Garel. 2000. Increased production of hydrogen peroxide by Lactobacillus delbrueckii subsp. bulgaricus upon aeration: Involvement of an NADH oxidase in oxidative stress. Appl. Environ. Microbiol. 66:262-267.

Meile, L., W. Ludwig, U. Rueger, C. Gut, P. Kaufmann, G. Dasen, S. Wenger, and M. Teuber. 1997. Bifidobacterium lactis sp. nov., a moderately oxygen tolerant species isolated from fermented milk. Syst. Appl. Microbiol. 20:57-64.

Rybka, S., and G. H. Fleet. 1997. Populations of Lactobacillus delbrueckii ssp bulgaricus, Streptococcus thermophilus, Lactobacillus acidophilus and Bifidobacterium species in Australian yoghurts. Food Aust. 49:471-475.

Sgorbati, B., B. Biavati, and D. Palenzona. 1995. The genus Bifidobacterium. Pages 279-306 in The Genera of Lactic Acid Bacteria. B. J. B. Wood and W. H. Holzapfel, eds. Blackie Academic, London.

Shah, N. P., J. F. Ali, and R. R. Ravula. 2000. Populations of Lactobacillus acidophilus, Bifidobacterium spp. and Lactobacillus casei in commercial fermented milk products. Biosci. Microflora 19:35-39.

Shah, N. P., W. E. V. Lankaputhra, M. L. Britz, and W. S. A. Kyle. 1995. Survival of Lactobacillus acidophilus and Bifidobacterium fibidum in commercial yoghurt during refrigerated storage. Int. Dairy J. 5:515-521.

Shimamura, S., F. Abe, N. Ishibashi, H. Miyakawa, T. A. Yaeshima, and M. Tomita. 1992. Relationship between oxygen sensitivity and oxygen metabolism of Bifidobacterium species. J. Dairy Sci. 75:3296-3306.

Smart, J. B., and T. D. Thomas. 1987. Effect of oxygen on lactose metabolism in lactic streptococci. Appl. Environ. Microbiol. 53:533-541.

Soon-Young, S., and J.-H. Park. 1997. Activities of oxidative enzymes related with oxygen tolerance in Bifidobacterium sp. J. Microbiol. Biotechnol. 7:356-359.

Sun, M., and S. Zigman. 1978. An improved spectrophotometric assay for superoxide dismutase based on epinephrine autoxidation. Anal. Biochem. 90:81-89.

Talwalkar, A., K. Kailasapathy, P. Peiris, and R. Arumugaswamy. 2001. Application of RBGR - a simple way for screening of oxygen tolerance in probiotic bacteria. Int. J. Food Microbiol. 71:245-248.

Talwalkar, A., K. Kailasapathy, J. Hourigan, P. Peiris, and R. Arumugaswamy. An improved method for the determination of $\mathrm{NADH}$ oxidase in the presence of NADH peroxidase in lactic acid bacteria. J. Microbiological Methods 52(3):333-339.

Uesugi, I., and M. Yajima. 1978. Oxygen and "strictly anaerobic" intenstinal bacteria: 2. Oxygen metabolism in strictly anaerobic bacteria. Z. Allg. Mikrobiol. 18:593-601.

Yamamoto, Y., M. Higuchi, L. B. Poole, and Y. Kamio. 2000. Identification of a new gene responsible for the oxygen tolerance in aerobic life of Streptococcus mutans. Biosci. Biotechnol. Biochem. 64:1106-1109. 